\title{
Adrenal Cortex Oncocytic Adenoma
}

National Cancer Institute

\section{Source}

National Cancer Institute. Adrenal Cortex Oncocytic Adenoma. NCI Thesaurus. Code C48447.

A usually non-functioning variant of adrenal cortex adenoma, composed of large cells with abundant granular eosinophilic cytoplasm. 